\title{
Applied Drama and Theatre - Drama Techniques in Teaching English for Specific Purposes
}

\author{
Gabriella KOVÁCS \\ Department of Applied Linguistics \\ Sapientia University Cluj-Napoca \\ Faculty of Technical and Human Sciences Târgu-Mureş \\ kovagabi@yahoo.com
}

\begin{abstract}
Theatre is a source to which teachers often turn for fresh ideas and methods. This study tries to unfold and follow the path which leads from theatre and drama to institutional education, and reveal the complex interdisciplinary connections and relations which have made it possible to use some of the experiences and methods accumulated in the field of actor training and applied drama and theatre in teaching English for specific purposes.
\end{abstract}

Keywords: applied drama and theatre, drama pedagogy, language teaching, interdisciplinarity

\section{Introduction}

I faced the much debated problem of our education system - that it does not prepare people for life and their future profession - when I started my career as a teacher, fifteen years ago. We accumulate theoretical knowledge along our school years and university studies, which we do not know how to use in practice. As a student, I often used to ask, and then as a teacher I often faced the following questions: "What is the purpose of learning such things?", "What are we going to use this for?" As teachers, we have two possibilities: to accept the situation as it is or try to find alternative methods which might turn the teaching-learning process into a more interesting and fruitful activity. The use of drama techniques could be one such alternative method.

In the research presented in this paper, I tried to find answers to questions referring to two main areas. The first refers to the connections leading from the domain of theatre and drama to language teaching. Why have some actor training techniques become so popular and adaptable in education, personality development or psychotherapy? Why is the domain of theatre the source to which language teachers - and teachers of many other subjects - turn so often for 
new ideas and methods? Which are those interdisciplinary connections among the domains of theatre, pedagogy, psychology, sociology and philosophy that make such influences possible? The second area refers to the presence and use of drama techniques in language teaching. The positive effects and usefulness of drama techniques in language teaching have already been proved and described. Most language teachers are convinced that role-plays and drama techniques can help students become more interested and involved in classroom activities, and integrate the newly acquired knowledge through actively seeking new and creative solutions, addressing different problems, exploring alternatives. In my research, I conducted a needs analysis to explore whether these techniques are considered equally helpful in teaching English for specific purposes.

The topic of this research required an interdisciplinary approach. In order to find the connections and relations that link actor training and applied drama and theatre to language teaching, I appealed to several disciplines (theatre, pedagogy, psychology, sociology, philosophy and linguistics).

\section{Theatre and pedagogy - personality development in acting pedagogy}

Different manifestations of the influence of theatre upon pedagogy can be traced in almost any level or area of education. But what new theatrical trends, experimentations and actor training techniques - mainly from the $20^{\text {th }}$ and the first decade of the $21^{\text {st }}$ century - led to the influence of this art form upon pedagogy?

The theatre of the $20^{\text {th }}$ century tried to renew its community-building power, which in the history of humanity has been present since the ancient rites, ritual games and religious ceremonies, where the audience was not passive but actively involved in the process. Several theatre theorists and practitioners realize and state that the "traditional theatre", which started to seem more and more fossilized and unnatural, should be replaced by new forms, ideas. Lehmann thinks that the theatre has to become a place for real gatherings and heavy bodies and objects, where everyday life and aesthetically organized life intersect, in order to be able to find and keep its place in the world of advanced media and technology. The action takes place "here and now", the time spent in the theatre is a time which the actors and the audience spend together (Lehmann 2009: 10). When Brook spoke about the immediate theatre proposed by him, he emphasized an important characteristic of the theatre - that it manifests itself in the present. The uniqueness of its function resides in its possibility to offer such a common experience, which cannot be achieved or found in films or on the scenes of everyday life - at home, on the street, at the psychologist or among friends (Brook 2008: 111-112). 
The new tendencies in theatre have had a great impact upon the development of methods used in acting pedagogy. According to Balme, this is such a field in theatre arts where a variety of research areas intersect. He refers to general theories of the theatre, theories of acting and acting pedagogy itself as part of an attempt to a theatre reform. The first actor training manuals did not appear in Europe before the eighteenth century and formal, institutionalized actor training - schools and workshops - began only in the twentieth century. Before that, the profession was learned "on the job" mostly in informal apprentice systems. "From the point of view of theatre studies, acting pedagogy is an important and potentially very fruitful area of research. Despite the rise of workshops and other non-formalized instruction contexts, acting schools are still the most important point of entry into the profession. Their methods and philosophies of instruction seem to be increasingly eclectic, a mixture of tradition and individual preferences" (Balme 2008: 27).

Kaposi emphasizes that acting pedagogy cannot be and is not worth being studied separately. It has to be correlated with all those social, cultural, educational and economic processes that define our present (Kaposi 2009: 30). Actor training became an essential condition of theatre renewal. In Europe and America, Stanislavski is considered to be the starter of the great changes. His influence can be detected in some form in the ideas and practices of almost all the significant actor trainers. The influences (regarding ideas, principles and the use and innovation of certain activities) which the different outstanding personalities of the western world had upon each other - who often emerged from each other's workshop or school - can be observed along the development of actor training.

Along the $20^{\text {th }}$ century, there were more and more attempts which favoured the actor's creativity in the embodiment of the characters. In the actor training of theatres that concentrate on spontaneous community building, personality development plays an important role. Stress, discomfort or anxiety, the inhibitions and complexes caused by forced competitive spirit and the pressure to measure up to certain expectations can cause heavy problems not only to actors but also to other people trying to get on in other domains and professions. This is one of the reasons why it became possible to use the methods and techniques of personality development from the domain of actor training in other fields of education as well. Balme also stresses that "acting pedagogy can also be found in non-professional contexts, especially in the area of applied theatre, where the aim is less to achieve professional-level virtuosity than to foster integrative and consciousness-widening skills. In this context, acting can be seen as an empowering and participatory activity which emphasizes interpersonal interaction: Acting's combination of physicality and cognitive abilities, especially role-playing, make it a crucial element of many kinds of group-building activities" (Balme 2008: 27-28). 
I analysed the work of eighteen actor training schools and workshops as well as the principles and ideas of the personalities who have played a decisive role in the development of these methods and techniques, and by doing so they had a great influence upon other domains of pedagogy concerned with personality development. If I try to sum up briefly this analysis, it can be concluded that regarding the skills and qualities which should be developed in actors, Constantin Stanislavsky emphasized the importance of creativity, imagination, communication, affective cognition, emotional memory, concentration, and relaxation; in Vsevolod Meyerhold's biomechanical system, physical control, rhythmic awareness, responsiveness to the partners and the audience, teamwork are essential; Jacques Coupeau concentrated on simplicity, spontaneity, sincerity, naturalness, playfulness and overcoming different inhibitions. Mihail Chekhov stresses the importance of imagination, concentration, "higher ego", the creation of atmospheres, radiation, style and the "four brothers": feelings of ease, feelings of the whole, of form and of beauty. Bertolt Brecht favoured observation, recognition, curiosity, teamwork and interactivity, empathy and critical attitude. Joan Littlewood pointed out the relevance of the development of teamwork, communication, flexibility, imagination, openness, trust and the overcoming of inhibitions. Lee Strasberg - similarly to Stanislavsky - emphasized the importance of relaxation, concentration, emotional memory and awareness, and the overcoming of inhibitions. Stella Adler highlights the significance of imagination (as actors relate to the given circumstances of the play), fantasy, creativity, sympathy and physical action. In Jerzy Grotowski's work, physical awareness, physical action, communication and the development of creativity are the most important. Neva Boyd and Viola Spolin emphasized the importance of the development of imagination, playfulness, spontaneity, creativity, problem-solving, team spirit, intelligence, sensibility, empathy, self-discipline, self-knowledge, self-expression and social adaptability. For Peter Brook, openness, directness, "transparency", communication, team spirit, receptiveness, sensibility, intuition, connectedness and responsiveness proved to be important. In Augusto Boal's work, the overcoming of inhibitions, interactivity, creativity, communicative competence, spontaneity, openness, the expressivity of the body, emotional and physical flexibility and physical awareness are significant. Keith Johnstone and his followers - Tom Salinsky and Deborah Frances White - emphasize the importance of spontaneity, creativity, fantasy, selfconfidence, the overcoming of inhibitions and relaxation. According to Joseph Chaikin, actors should try to enhance their creativity, openness, associative ability and team spirit. Next to the priorities mentioned in Chaikin's work, Robert Cohen finds it important to develop trust, discipline, playfulness, receptivity, spontaneity and co-operation. Anne Bogart thinks that creativity, spontaneity, intuition, cooperation, conscious interaction, team spirit, concentration, self-discipline and physical awareness should be developed. 
As several experts have stated, the most effective activities of personality development in actor training are the improvisations. Personality development includes the development of creativity, self-expression, relaxation, interactivity, spontaneity, playfulness, inventiveness, self-confidence, sincerity, motivation, communicative competence, concentration, self-discipline, empathy, cooperation, team spirit, trust, intelligence, fantasy, sensitivity, problem-solving, overcoming inhibitions, memory and emotional memory, physical awareness etc. I think it is important to emphasize that the above mentioned qualities and skills can be very useful in other professions as well.

The amount of experience regarding personality development and the related experiments and results, techniques and activities accumulated in the field of actor training in the $20^{\text {th }}$ century and the beginning of the $21^{\text {st }}$ century are remarkable. Consequently, certain actor trainers realized that these activities can be used in other domains as well, especially with educational or therapeutic purpose. Experts from other fields - teachers, educators, psychologists, doctors and sociologists - also recognized the potential possibilities which these games, exercises and different activity types can offer. That is why ideas and projects like those from the field of applied drama and theatre came into existence.

Games are considered to be an important means and activity form in actor training as this has been highlighted by some actor trainers - for example, Jacques Copeau (Copeau in Rudlin 2010: 59), Joan Littlewood (Littlewood in Baker 2010: 131), Neva Boyd (year unknown), Viola Spolin (1963), Peter Brook (2008), Keith Johnstone (1989), Robert Cohen (1992, 2007), or Tom Salinsky and Deborah Frances-White (2010). The participants in actor training are usually adults, and - according to Ruszt - playing is the distinctive characteristic of their profession, playing games is what differentiates acting from other professions. According to him, the real depth and the secrets of playing techniques can be discovered only by those who have not lost their skills to fantasize and imagine things like they used to when they were children (Ruszt 2005: 14).

\section{Applied theatre and drama}

The new tendencies that appeared in the domain of theatre arts and actor training in the $20^{\text {th }}$ century led to the appearance of new theatre forms, the aim of which is personality development, the improvement of the life quality of different groups, communities or individuals, and the creation of a better world. Actors and nonactors use theatre and drama techniques to generate social, political changes and personality development. Through applied drama and theatre, new connections and interdisciplinary co-operation became possible among different domains opening new possibilities for lifelong learning. 
The appearance of applied drama and theatre is closely connected to the social and political changes that occurred in the twentieth century and to a new way of thinking and world conception shaped and influenced by wars, political movements, globalization, consumerism, and the endless flow of information in the age of multimedia. Theatre, just like other art forms, tries to react to these problems by flexibly expanding its influence and sphere of action.

According to Sz. Deme, the change in the role of the audience was based on the recognition - more precisely a new recognition - of the fact that drama and theatre events represent an ancient and basic human need, and by this he means not simply "facing" or "witnessing" such events but the possibility of immediate and conscious feedback. With this goal in mind, the intention of theatre art is something more than simply to impress the audience. In the moment of the generated effect, the performers gain inspiration from the spectator's feedback, which influences the further development of the play (Sz. Deme 2010: 14).

Along with these efforts to create a new type of actor-spectator relationship, a growing interest could be detected regarding a new trend to use theatre techniques for educational or therapeutic purposes. In fact, this has not been such a new idea after all. According to Ackroyd, the use of theatrical forms to achieve such intentions as to inform, to unify, to instruct or to raise awareness is not new. It is the term of applied drama and theatre which is new. The Ancient Greeks used plays for therapeutic reasons - they intended to cleanse through catharsis (Ackroyd 2000). Balme mentions that the Jesuits also used theatrical forms for language teaching and propaganda (Balme 2008: 183).

A revival of interest in theatrical forms as an educational or therapeutic tool, which led up to the rise of applied drama and theatre, could be observed at the beginning of the $20^{\text {th }}$ century. According to Balme, one of the reasons of this phenomenon was the influence of Freudian psychoanalysis, and another reason was a growing interest in spontaneity and improvisation. Psychiatrist Jacob Levi Moreno organized theatre games for children in Vienna during the First World War, and then, turning his attention to adults, he organized theatre events based on improvisation under the name of The Theatre of Spontaneity. These attempts to create spontaneous performances helped him to work on the psychodrama concept and method, which he developed mostly in the USA. Moreno was inspired by Freudian psychoanalysis, but instead of the one-toone analyst-patient relationship and subject-centredness of psychoanalysis he concentrated on interpersonal interaction. He was convinced that most problems result from people's interpersonal relationships, so they have to be made explicit. A growing interest in spontaneity and improvisation could be detected in Neva Boyd and Viola Spolin's work, whose experiments were based on education through games and improvisation. Most forms of applied theatre use improvisational techniques and games, and share Boyd and Spolin's 
belief that human beings are "innately spontaneous and capable of creative expression” (Balme 2008: 183-184).

Joan Littlewood's ambitious project, The Fun Palace, can be considered another antecedent of applied drama and theatre. Helen Nicholson emphasizes the visionary characteristic and novelty of the project, the goal of which was to "afford the therapy of theatre to everyone", as Littlewood wrote in an article (Littlewood in Nicholson 2005: 1). She hoped that with the help of theatre techniques people of the deprived East End of London - shop and factory workers - could counteract the daily boredom and frustrations of their unsatisfying working lives. Unfortunately, this project could never materialize and The Fun Palace was never built because bureaucratic city councillors were not interested enough in developing such entertaining approaches to lifelong learning. However, Littlewood did not give up her dream and invited young people with different social problems to her East 15 Theatre trying to help them with the tools offered by drama techniques."It is an optimistic story, bearing witness to the power of drama to affect social and personal change" (Nicholson 2005: 1).

According to Sz. Deme, experiential, alternative, independent theatre forms and performances, which aim to change, shake and motivate to action our society, are considered to be closely linked to Artaud and Brecht's ideas and principles. According to them, theatre arts should take part in the education of the individual and the community. In a society facing several new challenges, both of them aspired and strived to shape a new approach and attitude of the spectators. Artaud believed that this could be carried out on a metaphysical level, inspired by the world of the mystics of the east, of rituals and magic ceremonies. He saw the possibility to cure society with the help of a theatre which ends in plague, total crisis and death or complete healing for the spectator (Artaud in Sz. Deme 2010: 21). This means that the person suffering under the pressure of social tension perishes as a result of the disease and crisis, and a new, "total human being" is born (Sz. Deme 2010: 21).

Brecht, instead of turning to mysticism, tried to activate the critical attitude and the participatory intentions of the spectators in order to initiate some changes in the process of reshaping society. Balme points out that Brecht's idea of Lehrstück can be considered an important step towards applied drama and theatre by combining theatre and pedagogy with a political purpose. The basic idea in the Lehrstück was that it tried to teach by being performed and not by being seen. The Lehrstück could be presented before an audience, but in principle it did not require spectators. The plays were not performed by professional actors but by amateurs, and the main goal was to make them understand that certain actions and attitudes can have different implications and impacts, and that society is not fixed or unalterable but it can be changed. According to Balme, "the Lehrstück is exemplary for much applied theatre because it is directed at the participants and not a 'passive' audience. If 
spectators are present, then it is expected that they will engage in discussion with the performers. (...) The spectators can provide suggestions, which may then be taken up and played through. In this sense, the Lehrstück anticipates the principles of an emancipatory pedagogy that today's applied theatre usually associates with the work of Augusto Boal" (Balme, 2008: 185).

Performance art can be regarded as another antecedent of applied drama and theatre because of its main aim to involve the spectators into the action, to influence and change them.

Based on the above mentioned examples, it can be concluded that in the $20^{\text {th }}$ century there could be observed a growing number of trends and experiments which relied on the personality of the spectator-actors, where the spectators did not witness previously chiseled interpretations and explanations, but they encountered problems which made them think or triggered spontaneous reactions. They became partners in the performance, they were offered the possibility to find the truth for themselves and make their own decisions.

Applied drama and theatre is a relatively new, interdisciplinary domain in full development, which tries to meet and respond to the needs of certain social groups. It includes all those theatre forms which focus on personality development or social change attainable with the means of theatre techniques. Ackroyd points out that many of those who work on a certain specific field of applied drama and theatre are not aware of those who fall in the same category. "The dramatherapist sees her work as distinctly different from that of the group who employ drama to enhance the skills of a company sales team. The prison theatre practitioner will not necessarily relate to those using drama to support the elderly. The practitioners in each group will see themselves working with specific skills appropriate to their work and therefore not the same as those in other fields. How then can we gather diverse practices into one bundle? [...] I suggest that it is an intentionality which all the various groups have in common. They share a belief in the power of the theatre form to address something beyond the form itself" (Ackroyd 2000). The intentions - to inform, to cleanse, to instruct or to unify - may, of course, vary. Different specializations can be observed, with various goals and directions, but the connection with the mainstream theatre is always there.

An important question refers to the terms applied drama and applied theatre, whether it is possible to make a clear distinction between the two or they refer basically to the same thing. Philip Taylor has tried to define the difference between them: "While there are similarities with applied drama, what one tends to find in the latter is a dependency on conventional British drama in education strategies to teach about issues, events, relationships. Applied theatre is powered by a strong sense of aesthetic education and is usually centered on structured scenarios presented by teams of teaching artist-facilitators" (Taylor in Nicholson 2005: 4). Nicholson thinks that this sounds like an extension of the distinctions 
usually made between drama in education (DIE), which is regarded as a processcentred teaching methodology, and theatre in education (TIE), which involves teachers and actors working with students in participatory performance projects. But, according to Nicholson, such differentiation is not justified as far as the terms are "used quite flexibly and interchangeably" in the literature of this domain (Nicholson 2005: 4). I agree with Nicholson in this matter, and that is why I chose to use the mixed term applied drama and theatre in this study.

Different attempts from the field of theatre, pedagogy, psychology, sociology or even politics, with the common goal of improving the quality of life of different groups or individuals, can be listed under the umbrella term applied drama and theatre. It is an interdisciplinary domain where theatre is closely connected with other disciplines like philosophy, psychology, pedagogy, sociology, anthropology etc.

This theatre form does not require traditional theatre buildings or stages. Prendergast and Saxton point out that the performers or participants are not necessarily trained, professional actors and the spectators usually belong to a group or community the problems of which are debated and discussed in the play, or are interested in the topic for some other reasons. "Whereas traditional mainstream theatre is most often centered in the interpretation of a pre-written script, applied theatre, in contrast, involves both the generation and the interpretation of a theatre piece that in performance may or may not be scripted in the traditional manner. In those cases where an applied theatre performance takes the form of a polished improvisation, a formally written script may never be recorded" (Prendergast and Saxton 2009: 7). According to Prendergast and Saxton, other important characteristics of applied drama and theatre practice are the following: "focus on multiple perspectives; disregard for sequence as fundamental to effective structure; endings that remain open for questioning; less reliance on words; more exploration of movement and image as theatre language; greater reliance on polished improvisation; theatre as a close, direct reflection of actual life with an overt political intent; to raise awareness and to generate change; a collective approach to creating theatre pieces in which the makers themselves become aware and capable of change; issues of local importance that may or may not be transferable to other communities; audience as an important and active participant in the creation of understanding and, often, of the action" (Prendergast and Saxton 2009: 11).

Accordingly, theatre and drama techniques can have remarkable educational, community-building and personality-changing effects if they become accessible and tangible to participants and spectators. Applied drama and theatre is a "participatory" theatre form, where spectators play some kind of roles as well, they are in interaction with the performers, and by doing this they become more deeply involved in the topic. 
There are several theatre forms which can be included into the category of applied drama and theatre (Popular Theatre, Psychodrama and Sociodrama, Theatre of the Oppressed, Theatre for Development, Prison Theatre, Communitybased Theatre, Museum Theatre, Reminiscence Theatre, Theatre in Health Education, Drama Pedagogy). All these activity forms function as tools of personality and community development.

\section{Drama pedagogy - the link between theatre arts and institutional education}

Drama pedagogy is mainly concerned with personality development and the development of communicative competence, and it has two main branches: Theatre in Education (TIE) and Drama in Education (DIE).

TIE was developed as a new theatre form in Great Britain in the 1960s, when due to progressive government policies more funds were directed toward arts and education, and theatre companies started to create new programmes for the communities. Some companies chose to work together with schools and plan theatre plays together with the children and teachers. The plays were chosen according to the children's age, interests and the school curriculum. "Because they were dealing with audience participation and curriculum, the actors who worked at and toured into the schools were required to gain an understanding of and ability to achieve effective teaching. The result of these developments was a new genre of theatre - theatre in education - and a new kind of actor, called an actor-teacher. Conversely, for teachers in schools, this new practice became an opportunity for professional development and training in drama/ theatre education. Teacher workshops, and the direct involvement of teachers in developing and implementing materials that prepared and followed-up each performance, became of central importance in delivering and assessing the success of TIE projects" (Prendergast and Saxton 2009: 31-32).

Sz. Deme points out that this form of theatre and education can be related to both applied drama and theatre and reform pedagogy, and just like performance art it concentrates on raising questions and it tries to turn the spectators into partners by involving them in the act (Sz. Deme 2010: 25). The success of TIE lies in the flexible and open arrangement of theatrical and educational elements. The communication and feedback between actors and spectators is essential. Discussions, where all the actors, teachers and spect-actors participate, are important moments of these events because here they have the opportunity to share their feelings, impressions and opinions.

The involvement and participation of the spectators can vary. According to O'Toole, there are situations when the events are planned for a more passive 
audience, and the power of the dramatic plot and the theatrical effects are meant to be used for educational purposes. In other situations, the spectators are expected to get verbally involved or act on the stage, becoming part of the plot development. TIE makes it possible for the participants to meet actively with the created experience, and by this to get involved and fully live the experience. If the spectators can influence the plot, the nature of the experience is different, more intense. The depth of the discovery and involvement can be remarkable, the situation may be imagined, but the action and happening from it are real (O'Toole 1995: 31). According to Sz. Deme, the spectators are awarely present from the very beginning, they control what is happening with them, and sometimes they are invited to help in setting the rules of the event. Taking part in all the phases of the action, they become more aware of the responsibility they have for their reactions. The process which is shaped by the co-operation of the conscious spectator transcends the effects of the theatre and points in the direction of social utility. This is becoming a more and more important goal for theatre makers (Sz. Deme 2010: 28).

DIE is a method based on pedagogical and pshychological principles, and compared to the other forms of applied drama and theatre it is probably the most process-centred. DIE can make teaching different subjects more efficient. Thanks to its process-centredness, it is also called Process Drama, mostly in the United States and Australia.

DIE was developed from the practice of "as if" games. It is a personalitycentred method, often associated with reform pedagogy, which aims to develop creativity, spontaneity and communicative competence, preparing students to face real-life situations with less difficulty. Playing games is an important part of this method, because - as it was proved by psychology - games play an important role in the development of the personality. Debreczeni points out that in DIE the participants discover the surrounding world, their own inner world, and the world of the society through group activities and intensive communication. From this process, they can gain moral sensitivity, emotional balance and stability, creative thinking and self-knowledge (Debreczeni 1992).

According to Gabnai (1999), personality development is the main goal of drama in education, which is done through different situational games or role-plays. There is no audience, but the presence of peers helps students to develop selfconfidence and the ability to work in a team, and prepares them to communicate more easily in real-life situations. These activities can be considered rehearsals, where the participants have to speak and perform different tasks in the middle of attention, practising through this the readiness and inventiveness necessary in different social roles and situations of everyday life. Drama games can increase the self-knowledge and insight into the human nature of people working in and for a community. Dynamic thinking, a focused and well-planned working method, and clear, coherent, emphatic way of speaking can be developed through them. They 
can compensate to a certain extent for the passivity generated by the development and spreading of mass media. Drama games offer collective experience through which the participants can encounter the pleasure of self-expression and recognition and develop their decision-making and problem-solving skills.

The socializing effects of drama in education can bridge the gap between institutional education and real life because they can help the students to acquire the necessary skills, behaviour and knowledge to improve their performance in different professions, and their ability to perform certain specific roles.

Gavin Bolton (1993), the internationally recognized drama educator and theorist of drama in education, called the method developed by him drama for understanding, which can be very useful in teaching different subjects. In these activities, the participants work in groups and create an imaginary world where they "play" different roles. In this world, they encounter the same kind of problems as in the real world, thus acquiring real knowledge and experience.

According to Heathcote, in drama games and role-plays, the acts of the participants are deeply influenced by their previous experience and knowledge. This is a complex pedagogic method through which the real problems of life can be dealt with in a protective environment, facilitating learning through experience (Heathcote 1995).

From the point of view of my topic, it is important to emphasize that there is a strong connection between drama and the acquirement and use of language and communication skills. Bolton stated that from several viewpoints drama is the language itself and language in drama activities is the means that helps participants to understand the meaning of things. He speaks about language in its widest sense as the verbal and non-verbal code for understanding and sharing an experience (Bolton 1993: 86-88).

\section{Theories which justify and support the use of drama pedagogy in institutionalized education}

In this part of my research, I analysed a few important theories, which in my opinion support and justify the use of drama pedagogy in institutionalized education. These theories are the following: experiential learning (life-long learning based on experience); Csíkszetmihályi's (2001) flow theory (and the connection between the peak experience and the learning process); constructivist pedagogy (and the constructive drama defined by Gábor Takács (2009); Goffman's (1999) theory about the presentation of the self in everyday life (and the interrelations and connections between playing roles on the stage and in everyday life).

One of drama's most important roles in education is that it prepares the participants for real-life situations through experience, experimentation and 
joyful activity. These theories support the important benefits which drama activities offer: a safe environment where the participants can speak and act free of constraints and inhibitions, discover their needs, skills and talents, learn to find and identify the objective truth, create their own ideas and images of the world, and develop their senses and reflectiveness.

I find it important to point out the parallelisms between playing roles on the stage and in everyday life, based on Erving Goffman's theory. One of the main thoughts of this study is that the experience, methods and techniques of actor training can be adopted and used in education and personality development because these parallelisms exist between role-plays on stage and role-plays in real life. If I approach the possibilities offered by drama pedagogy from the point of view of my final goal - using drama techniques in teaching English for specific purposes -, it becomes obvious that these activities can help in the development of speaking skills and the presentation of the self in the target language in everyday life situations. It is more difficult to shape in the way we would like to what others see in our performance or what others think of us in a target language situation, mostly because of the inhibitions caused by the possible language barriers, by the imperfections of our target language knowledge. I believe that this can be helped by using drama techniques - role-plays or simulations - in the language class.

\section{Drama techniques in language teaching}

\subsection{The premises and presence of drama techniques in different methods along the history of language teaching}

Role-plays and drama techniques have always been present along the history of language teaching, but they have been used to various extents by means of different methods. Even in the time of the grammar translation method, there were language teaching theorists who tried to introduce innovatory techniques. Towards the end of the nineteenth century, the natural approach methods emphasized the importance of speaking practice as opposed to grammar and translation exercises, encouraging interaction, contextualization and physical activity.

The main principle of the direct method was the use of the target language and the avoidance of the mother tongue; therefore, demonstration, the use of gestures and mimics were essential and inevitable. Role-plays, drama, and physical activity gain more importance in the audio-lingual method, where the need for experiencing and discovering the use of language in context grows.

According to Bárdos, humanistic methods could also be called dramatizing methods. They are based on personality-centred and psychological approaches, where the development of the whole personality of the language learner is taken 
into consideration. In Asher's method, called Total Physical Response (TPR), the students have to respond with action to instructions given in the target language. Asher was aware of the importance of physical activity and emotional factors in the language learning process. The dramatic features in Gattegno's silent way approach are the movements, gestures and mimics of the teacher, whose silent performance has to be interpreted by the students in the target language. In Curran's community language learning (CLL) method, the emotional factors, mutual trust and a relaxed atmosphere are considered important in the learning process. The main principle in Lozanov's suggestopedia is the creation of a tension-free atmosphere in which students feel confident and comfortable. Drama, games, music and songs are widely used in this method (Bárdos 2005).

Games, role-plays, drama techniques, group discussions and simulations became even more popular in the learner-centred communicative language teaching. This trend opens the door to learning based on personal experience and discovery in interactive environments created by information gaps and problemsolving situations.

\subsection{Characteristics and main goals of drama techniques in language teaching}

Alan Maley and Alan Duff define dramatic activities in a language classroom as follows: "They are activities which give the student an opportunity to use his or her own personality in creating the material on which part of the language class is to be based. These activities draw on the natural ability of every person to imitate, mimic and express himself or herself through gesture. They draw, too, on the student's imagination and memory, and natural capacity to bring to life parts of his or her past experience that might never otherwise emerge. They are dramatic because they arouse our interest, which they do by drawing on the unpredictable power generated when one person is brought together with others. Each student brings a different life, a different background into the class. We would like students to be able to use this when working with others" (Maley \& Duff 1991: 6). According to them, most traditional textbooks give little attention to the skills we need most when using a language: adaptability, sensitivity to tone, speed of reaction, insight and anticipation, in one word: appropriateness. This neglected emotional content can be put back into language through drama, giving more attention to the real meaning of the structures that are being taught.

Some of the activities used in language teaching - mime, language games, group discussions, role-plays and simulations - can be gathered under the umbrella term drama techniques. Role-plays can be considered the most widely spread of these because, to different extents, they can be present in all the other types. 
Alan Maley defines the concept of role-play in language teaching as follows: "The term 'role-play' calls to mind the fable of the blind man trying to describe an elephant; the term takes on different meanings for different people. It certainly seems to encompass an extremely varied collection of activities. These range from highly-controlled guided conversations at one end of the scale to improvised drama activities at the other; from simple rehearsed dialogue performance to highly complex simulated scenarios." (Maley in Porter Ladousse 2009: 3)

According to Porter Ladousse, in "role-play", the term play means that students can play a part - someone else's or their own - in a safe environment which ensures ideal conditions for playfulness and inventiveness. Students, just like children playing doctors and patients, unconsciously create their own reality, and through this experiment, with their knowledge of the real world, they develop their interacting skills with others. Unlike in a theatre, in the classroom there are no spectators, and they do not feel threatened by the risks of behaviour and communication which are present in the real world. Thus, the activity is more enjoyable, and playing a role in such a relaxed atmosphere can help building up self-confidence. The flexibility of role-plays opens the door to individual ideas, variations and initiatives, and develops creativity, offering direct experience of the unpredictable nature of the target language in use. Ladousse sums up the most important advantages of role-plays, emphasizing their benefits and characteristics. A wide range of language structures, functions and vocabulary can be introduced and practised through role-plays, offering a large variety of experience and training in speaking skills in different situations; in role-plays, students are required to develop and use the phatic forms of the target language which are necessary in social relationships; for students who are learning a language to prepare for specific roles in their professional life (e.g. in English for specific purposes), role-plays can function as rehearsals for real-life tasks; they provide shy students a kind of mask which helps them overcome their difficulties in participating in conversations; role-plays are entertaining, fun for students; they develop fluency, promote interaction and increase motivation. The main difference between a role-play in the classroom and a dramatic performance is that the first is mainly concerned with the process of playing a part and not the finished product. Students carry out the activity for themselves, in a team where ideally everybody is equally involved. As humanistic tendencies in education have shown, the learning process can be more efficient in a tensionfree atmosphere. The follow-up or debriefing is an important part of the activity, where the teacher should insist on evaluation rather than criticism, encouraging positive thinking about the experience (Porter Ladousse 2009: 5-17). 


\subsection{Needs Analysis - Role-plays in Teaching English for Engineering}

In this part of my paper, I present the results of a needs analysis, which was conducted with 106 engineering students and engineers about their language learning needs and habits, their experience and opinion regarding role-plays and the popularity and usefulness of role-plays in learning English for specific purposes (ESP). They were also enquired about the specific situations and roles in which they have to use the target language in their work.

The results of the needs analysis show that the majority of the respondents think that developing their speaking skills and their professional communication skills is very important. Most of them are aware of the advantages of group work and like to work in a team. A great number of respondents like role-plays in ESP because they think these activities prepare them for better communication in different profession-related situations. The reasons given to support the usefulness of role-plays in ESP confirm the ones from the specialized literature: they prepare them for better communication in their profession; their language skills, especially speaking skills, can be improved; they learn from their own experience; they get to know themselves and others better; it is easier to learn in a playful, relaxed atmosphere; their power of thinking, self-confidence, problemsolving skills, team spirit and co-operation can be developed. It is important to emphasize that the vast majority of the respondents think that role-plays in ESP are useful, even those who do not like them.

Engineering students and engineers have to be prepared to use English within the workplace, in professional or academic environments. In ESP, the target language is studied to ease the way to enter these environments, or to gain greater communicative efficiency within them.

Designing role-plays might be challenging and time consuming for the teacher, but, taking into consideration the needs and the profession-specific communicative situations which our students will encounter in their future profession, this teaching technique can prove to be successful. Role-plays in ESP classes must reflect the problems, situations and tasks which can occur in their professional environment. These activities can reach their purpose only if students enjoy them and participate actively in them. Techniques from the field of drama in education can be of great help in achieving these goals.

\section{Conclusions}

The development of methods and techniques in actor training in the $20^{\text {th }}$ century - due to the fact that they concentrate on the development of the whole personality, communicative competence and team building - had a 
great influence upon the development of the methods and activity types of applied drama and theatre. Drama in education (DIE) and theatre in education (TIE) create a bridge between theatre and education, and this can be justified by theories regarding personality development, game theories, experiential learning, the flow theory, constructivist pedagogy and Erving Goffman's theory. Drama techniques have been present for a long time in language teaching because they are regarded as an effective alternative tool in developing communicative competence in the target language and the learners' ability to perform certain roles in the possible "scenes" of everyday life or their future professions. Adult learners who study English for specific purposes are aware of the fact that roleplays and simulations help them prepare for their future profession, and they like these activities and find them useful.

The interdisciplinary connections demonstrated in this paper are illustrated by the following diagram:

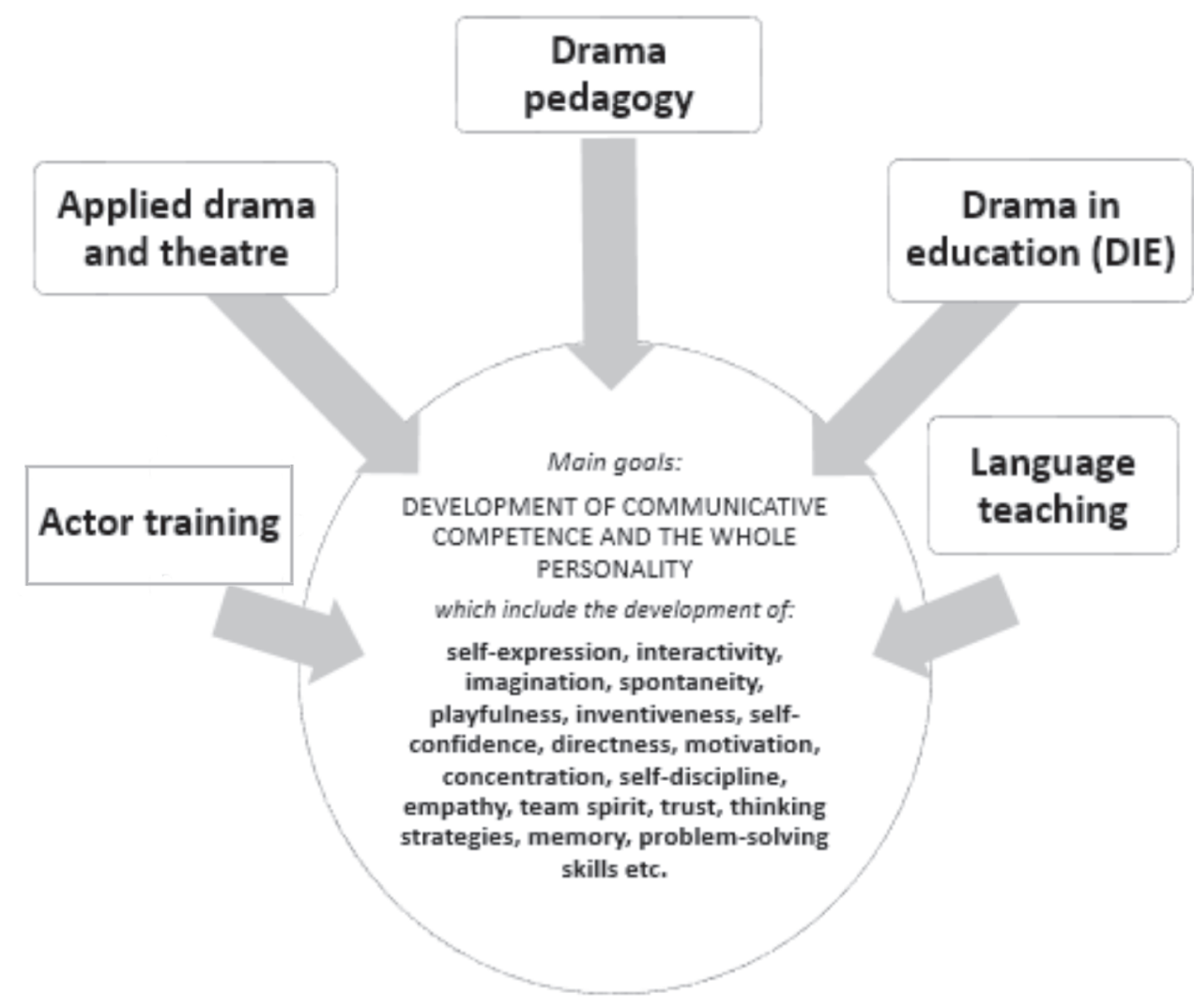




\section{References}

Ackroyd, Judith. 2000. Applied theatre: Problems and possibilities. In: Applied Theatre Researcher, Griffith University 1 (Accessed on: 2012-06-10; http:// www.griffith.edu.au/_data/assets/pdf_file/0004/81796/Ackroyd.pdf )

Balme, Christopher B. 2008. The Cambridge introduction to theatre studies. Cambridge: Cambridge University Press.

Bárdos, Jenő. 2005. Élő nyelvtanítás-történet. Budapest: Nemzeti Tankönyvkiadó. Barker, Clive. 2010. Joan Littlewood. In: Alison Hodge (ed.), Actor training. London- New York: Routledge. 130-143.

Boal, Augusto. 2002. Games for actors and non-actors. New York: Routledge. 2006. The aesthetics of the oppressed. London: Routledge.

Bogart, Anne-Landau, Tina. 2005. The viewpoints book: A practical guide to viewpoints and composition. New York: Theatre Communications Group.

Bolton, Gavin. 1993. A tanítási dráma elmélete. Budapest: Marczibányi Téri Múvelődési Központ.

1994. Az oktatási dráma és színházi nevelés összehasonlítása. In: Szauder, Erik (ed.), Dráma - oktatás - nevelés. Budapest: Nemzeti Tankönyvkiadó. 176-190.

Boyd, Neva (n.d.) The theory of play. (Accessed on: 2012-06-01; http://www. spolin.com/boydplaytheory.htm)

Brook, Peter. 2008. The empty space. Penguin Books.

Cohen, Robert. 1992. A színészmesterség alapjai. Pécs: Jelenkor Kiadó. 2007. Puterea interpretării scenice. Cluj Napoca: Casa Cărții de Ştiință.

Csíkszentmihályi, Mihály. 2001. Flow - Az áramlat. A tökéletes élmény pszichológiája. Budapest: Akadémiai Kiadó.

Debreczeni, Tibor. 1992. A drámapedagógia hazánkban. In: Drámapedagógiai Magazin 1. Budapest: Magyar Drámapedagógiai Társaság. 1994. Drámapedagógiai órák - alsóban, felsóben és fóiskolán. Kecskemét, Magyar Drámapedagógiai Társaság és a Kecskeméti Tanítóképző Főiskola.

Gabnai, Katalin. 1999. Drámajátékok. Bevezetés a drámapedagógiába. Helikon Kiadó, Budapest.

Goffman, Erving. 1999. Az én bemutatása a mindennapi életben. Budapest: Thalassa Alapítvány, Pólya Kiadó.

Heathcote, Dorothy. 1995. A konvenciókról. In: Kaposi, László (ed.), Drámapedgógiai Olvasókönyv. Budapest: Magyar Drámapedagógiai Társaság, Marcibányi Téri Múvelődési Központ.

Johnstone, Keith. 1989. IMPRO - Improvisation and the theatre. $6^{\text {th }}$ rev. ed. London: Methuen Drama.

Kaposi, József. 2009. A színházi nevelésről a színészképzés kapcsán. In: Drámapedagógiai Magazin 2009/különszám drámapedagógusoknak. Budapest: Magyar Drámapedagógiai Társaság. 30-32. 
Ledőné, Dolmányi M.-Szauder, Erik. 2004. Gondolatok a szakértői drámáról. In: Drámapedagógiai Magazin 1. Budapest: Magyar Drámapedagógiai Társaság.

Lehmann, Hans-Thies. 2010. Posztdramatikus színház. Budapest: Balassi Kiadó. Maley, Alan-Duff, Alan. 1991. Drama techniques in language learning - A resource book of communication activities for language teachers. Cambridge: Cambridge University Press.

2005. Drama Techniques. Third Edition - A resource book of communication activities for language teachers. Cambridge: Cambridge University Press.

Nicholson, Helen. 2005. Applied drama. The gift of theatre. Palgrave Macmillan. O’Toole, John. 1995. Színházi és drámai dimenziók. In: Kaposi, László (ed.), Színház és dráma a tanításban. Budapest: Kerekasztal Színházi Nevelési Központ - Magyar Drámapedagógiai Társaság. 30-43.

Porter Ladousse, Gillian. 2009. Role Play. Oxford: Oxford University Press.

Prendergast, Monica-Saxton, Juliana (eds.). 2009. Applied theatre: International case studies and challenges for practice. Bristol/Chicago: Intellect.

Richards, Jack. C.-Rodgers, Theodore. S. 1986. Approaches and methods in language teaching. Cambridge: Cambridge University Press.

Rudlin, John. 2010. Jacques Copeau: The Quest for Sincerity. In: Alison, Hodge (ed.), Actor training. London-New York: Routledge. 43-62.

Ruszt, József. 2005. Színészdramaturgia. In: Színház. Melléklet (December). 1128.

Salinsky, Tom-Frances-White, Deborah. 2010. The Improv Handbook. The Ultimate Guide to Improvising in Comedy, Theatre, and Beyond, New YorkLondon: Continuum.

Spolin, Viola. 1963. Improvisation for the theatre. Illinois/USA: Northwestern University Press.

Sz. Deme, László. 2010. A nézői szerep változása a nyugati színház történetében. In: Deme, János-Sz. Deme, László (eds.), Ha a nézố is résztvevôvé válna. Kísérletek a színház és a közönség viszonyának újragondolására. Budapest: L’Harmattan Kiadó. 13-36.

Szauder, Erik. 1994. Az oktatásban alkalmazott dráma értelmezése, tevékenységi körének bemutatása. In: Szauder Erik (ed.), Dráma - oktatás - nevelés. Budapest: Nemzeti Tankönyvkiadó. 5-23.

Takács, Gábor. 2009. „Konstruktív” dráma avagy a tanítási dráma kapcsolódása a konstruktív pedagógia néhány alapfogalmához. In: Deme, János (ed.), Színház és Pedagógia - „Konstruktív” dráma. Budapest: Káva Kulturális Múhely, AnBlokk Egyesület. 26-44. 